\title{
The Validity and Reliability Test of Modified Picture Vocabulary Test IV in 48-59 Months Old Children
}

\author{
Sumarni ${ }^{1}$, Amendi Nasution ${ }^{1}$, Luh KWahyuni ${ }^{1}$, Trevino Pakasi ${ }^{2}$ \\ 1 Department of Physical Medicine and Rehabilitation, Faculty of Medicine - University of \\ Indonesia, Jakarta \\ 2 Department of Community Medicine, Faculty of Medicine - University of Indonesia, Jakarta
}

\begin{abstract}
Objectives: To investigate the validity and reliability of Modified Picture Vocabulary Test IV (PPVT IV) in 48-59 months old child.

Methods 228 items in 19 sets of PPVT IV were translated in Indonesian language and revised according to Indonesian culture. One hundred and five 48-59 months old children were tested. The results were analyzed for its construct validity and reliability. The construct validity was valued by the correlation coefficient between the set score and the total score and the correlation coefficient between the item score and the set score. The reliability was valued by intra-class correlation coefficient, standard error of measurement (SEM) and Cronbach alpha.

Results: The construct validity of Modified PPVT IV was good $(r>0.256 ; \alpha=0.01 n=100)$ and the reliability was high (internal consistency with Cronbach alpha $=0.938$, inter-rater reliability $=0.957$ $0,985$ and standard error of measurement $(\mathrm{SEM})=6.4)$.

Conclusions: Modified PPVT IV was a valid instrument with satisfactory reliability. To increase the construct validity, there were 36 items that should be substituted.
\end{abstract}

Key Words: Modified PPVT IV, construct validity, internal consistency reliability, inter-rater reliability, standard error of measurement

\section{INTRODUCTION}

The prevalence of speech and language development delay in children had been research excessively. The prevalence rate of speech and language development delay from abroad research was range from 5-8 \% ${ }^{1}$. In Indonesia,

Received in March 2013 and accepted for published in April 2013.

Correspondence address: Sumarni, Jl. Tanjung Duren Barat III No. 26B, Jakarta Barat 11470. Email: sumarni_ stephen@yahoo.com the prevalence rate was range from $4.7-9.3 \% .^{2,3}$

The language development delay issue is important because it will affect the child quality of life later on. ${ }^{4}$ The result of the three longitudinal study showed that the language development was related to intelligence and reading ability afterwards. The language delay in early age is a strong predictor of low intelligence and reading difficulty 4-5 years later on. From that research, it is obvious that early intervention of children with speech and language delay is needed to prevent learning disability in school. 
Nowadays, in Indonesia there was no standardized test for evaluating the intervention success in one therapy for language delay. The standardized test is a language function evaluation test which is the most formal and decontextual. 5 The test was developed from research to a large amount of children with a normal language development and was counted for variation range that could be accepted. The benefit of this test, if made well, can be used to compare language development among children. The cause is that the standardized test has clear administration and scoring, good reliability and validity. One of the standardized test that is used in America is Peabody Picture Vocabulary Test (PPVT). ${ }^{6}$

This test had been modified in Mexican in $1976^{7}$ and Spanish in $1986 .{ }^{8}$ At this moment, there is no modified version in Indonesia. The researcher wanted to make the modified version in Indonesia according to Indonesian children culture and tested its validity and reliability. The PPVT IV itself has 2 forms, the Form A and the Form B. In this research, the Form A will be modified and tested for its validity and reliability.

\section{METHODS}

Research's samples were defined from selected population of samples using multi stage cluster random sampling. Inclusion criteria consist of all the kindergarten students which were 4859 months old, was permitted by their parents to follow this research, and passed the training items.

Exclusion criteria consist of a student which wasn't permitted by their parents, was sick when the test was held, had been diagnosed by a doctor had mental retardation, speech and language delay, vision impairment that couldn't be corrected, hearing impairment, learning disability, emotional and behavioral disorder, ADHD (Attention Deficit Hyperactive Disorder) and genius.

After getting the ethical clearance from faculty ethical committee, the cross sectional study was started. 228 items in 19 sets of PPVT IV were translated in Indonesian language and were revised according to Indonesian culture. One hundred and five 48-59 months old children were tested. The results were analyzed for its construct validity and reliability. The construct validity was valued by the correlation between the item score and the set score. The reliability was valued by intra class correlation coefficient, Standard Error of Measurement (SEM) and Cronbach alpha.

\section{RESULTS}

There were 21 items in PPVT that were not suitable with Indonesian culture. They were revised according to Indonesian culture and were noticed for their difficulty level based on the child age and word category.

According to research characteristic of the subject, one hundred and five 48-59 months old children were tested. The reliability of modified PPVT IV was high (internal consistency) with Cronbach alpha $=0.938$, inter-reliability $=0.957$ 0.985 and standard Error of Measurement (SEM) $=6.4$. The construct validity of Modified PPVT IV was $\operatorname{good}(r>0.256 ; \alpha=0.01 ; n=100)$. 
Table 1. Characteristics of Study Samples

\begin{tabular}{lc}
\hline \multicolumn{1}{c}{ Socio-demography characteristics } & $\mathbf{n}=\mathbf{1 0 5}$ \\
\hline Age $\left(\right.$ Months ${ }^{*}$ & $58(48-59)$ \\
Gender ** & $48(45.7)$ \\
Male & $57(54.3)$ \\
Female & $93(88.6)$ \\
History of Chronic Suppurative Otitis Media** & $12(11.4)$ \\
No & \\
Yes & $40(38.1)$ \\
Mothers Education Level ** & $56(53.3)$ \\
Average (Graduated from Senior High School) & $9(8.6)$ \\
High (Academy 1-3 years) & \\
Very High (Academy $>4$ years) & $88(83.8)$ \\
Bilingualism** & $17(16.2)$ \\
No & \\
Yes & $5(4.8)$ \\
Family Income ** & $77(73.3)$ \\
Low (<1 million/month) & $23(21.9)$ \\
Average (1-5 million/month) & \\
High $(>5$ million/month) &
\end{tabular}

$*=$ median (interquartil range), ${ }^{* *} \mathrm{n}(\%)$

\section{DISCUSSION}

In this modified PPVT IV, there were 21 items that were revised from its direct translation. In Mexican version there was no item that was modified from its direct translation. ${ }^{7}$ The modification was just made for the arrangement of the items according to the difficulty level. In Spanish version, 50 items were deleted because of the culture bias. ${ }^{8}$

The amount of children that were tested for this research is one hundred and five. Compare with estimated sample sum, which is one hundred, the sample in this research is over $5 \%$. If compared with PPVT IV research in America in 2004 (200 children), ${ }^{5}$ the sample amount of this research just reach $52.5 \%$ from that research. However, if compared with the research in Mexico, with 53 children, the sample amount of this research is quite lot. ${ }^{7}$

The Cronbach Alpha for Modified PPVT was 0.938. If compared with PPVT research in America, the Cronbach alpha for this version was lower $(r=0.965),{ }^{10}$ but it was almost similar with Spanish version $(\text { Cronbach alpha }=0.930)^{11}$ and higher than Mexican version (Cronbach alpha $=0.85) .{ }^{7}$ However, the Cronbach alpha value was more than 0.90 , so the reliability is high. ${ }^{12,13}$

Inter-rater reliability of this research was range from $0.957-0.985$. This reliability is higher than PPVT in America (0.93). ${ }^{14}$ This might be caused by adequate training and the good comprehension of the assistant.

The Standard Error of Measurement (SEM) in this research (6.4) is higher than research in America (3.3). ${ }^{14}$ It means the reliability of American PPVT is higher than its modification version.

The validity of Modified PPVT IV to measure verbal ability in this research was done by testing its construct validity. The construct validity was measured by looking at the correlation between each set score with total score of PPVT. Now, in Indonesia, there is no golden standard for measuring child verbal ability, so according to literature, it was taken general value as validity limit. ${ }^{15}, 16$ In this research, all $r$ value in each set was more than $0.256(\alpha=0.01 ; n=100)$. It means that all the sets of Modified PPVT IV can be used in determining PPVT IV score.

From validity test per set, there were 36 items that were not valid, (in set 
$1,2,3,4,5,6,7,8,11,18$, and 19). That items were not valid because the low variability, so that the correlation with total score were low, too. For example, the items 1,2,3,4,5,6,9,10,11 (appendix table 1); and 13,19 (appendix table 2), in which the all respondents $(100 \%)$ answered the items correctly, so the presence of that items did not affluence the set score.

The other items that were not valid or had low positive correlation showed that a child that answered the item correctly, this set score was low. So on the contrary, a child that answered the item incorrectly, this set score was high. The causes might be that the items confused the child, the drawing was not good so made misinterpretation, the item had no clear answer so the distracter had the chance to be chosen or was qualified as the correct answer, the item had distracter that almost children felt it was definitely right so the children guessed it was the right answer, there was gender, ethnic or subgroup bias in items or distracters. ${ }^{17}$ In this research, the researchers didn't record the answered items (1, 2, 3 or 4), nevertheless right or wrong answers. That is why it could not be analyzed further about the reason that was the most possible. But for increasing the validity of each set, the items that were not valid could be changed.

From 36 items that was not valid, there were 6 items $(16.67 \%)$ that were from revision output. The other items $(83.33 \%)$ were from direct translation. Thus, the big part of the revision outcome was valid.

The reliability and validity was quite high in this research, so it was proved that a language test could be translated. It can spare the energy, time and cost if compared with make a new test tool. ${ }^{7}$ This also suitable with "language universals" by Chomsky (1981) which stated that the languages in this world have the same foundation. The reason is that the language is correlated with human internal structure and human is the only one creature which has and uses language. So, the language is also based on universal concept based on neurology and biology similarity. ${ }^{18}$

The limitation of this research is that it just tested construct validity and internal consistency, inter-rater reliability and SEM of Modified PPVT
IV. There are another validity and reliability that had not been tested. The validity that had not been tested is predictive, content and external validity. The reliability that had not been tested is intra-rater test-retest, equivalent instrument test and consolidation test.

Besides, in this research, the respondents are more in 54-59 months old, so it did not make a normal age distribution.

Another limitation is that the modified picture is a photo, not a painting like the original version. This make this modified PPVT cannot be used in color blindness children.

\section{CONCLUSIONS}

Modified PPVT IV was a valid instrument with satisfactory reliability. To increase the construct validity, there were 36 items that should be substituted.

\section{REFERENCES}

1. Nelson H, Nygren P, Walker M, Panoscha $\mathrm{R}$. Screening for speech and language delay in preschool children: systematic evidence review for the US Preventive Services Task Force. Pediatrics. 2006;117:298-319.

2. Jaenudin E. Stimulasi keluarga pada perkembangan bicara anak usia 6-36 bulan di Kelurahan Kuningan, Semarang Utara [Thesis]. Semarang: UNS; 2000.

3. Wahyuni S. Pemeriksaan penyaring keterlambatan perkembangan bahasa pada anak balita dengan Early Language Milestone Scale di Kelurahan Paseban Jakarta Pusat [Thesis]. Jakarta: FKUI; 1998.

4. Silva P. Epidemiology, longitudinal course and some associated factors : an update. In: Yule W, Rutter M, editors. Language Development and Disorders. Oxford: Mac Keith Press, Blackwell Scientific Publication Ltd; 1987.p.1-15.

5. Paul R. Evaluation and Assesment. In: Paul $\mathrm{R}$, editor. Language Disorders from Infancy through Adolescence. 3rd ed. Philadelphia: Saunders Elsevier; 2007. p.41.

6. Paul R. Assesment of developing language. In: Paul R, editor. Language Disorders from Infancy through Adolescence. 3rd 
ed. Philadelphia: Saunders Elsevier; 2007. p.322-8.

7. Simon A, Joiner L. A Mexican Version of The Peabody Picture Vocabulary Test. Journal of Educational Measurement. 1976;13:137-43.

8. Dunn L, Padilla E, Lugo D. Test de Vocabulario en Imagenes PeabodyAdaptation Hispanoamericana. American Guidance Service; Circle Pines, MN: 1986. Peabody Picture Vocabulary Test- Latin American adaptation.

9. Riduwan, Sunarto. Validitas dan Reliabilitas. In: Akdon, editor. Pengantar Statistika untuk Penelitian Pendidikan, Sosial, Ekonomi, Komunikasi dan Bisnis. Bandung: CV Alfabeta; 2007. p.347-60.

10. Dunn L, Dunn D. Content development, tryout, standarization and norms development. In: Dunn L, Dunn D, editors. PPVT4 Peabody Picture Vocabulary Test Manual. Minneapolis: NCS Pearson, Inc; 2007. p.27-30.

11. Moeller M. Intervention and language development in children who are deaf and hard of hearing. Pediatrics. 2000;106:1-9.

12. Sugiyono. Statistik untuk pengujian validitas dan reliabilitas instrumen penelitian. In: Mulyatiningsih E, editor. Statistika untuk Penelitian. 12th ed. Bandung: CV Alfabeta; 2007. p.348-66.
13. Tumbelaka A, Riono P, Sastroasmoro S, Wirjodiarjo M, Pudjiastuti P, Firman K. Pemilihan Uji Hipotesis. In: Sastroasmoro $\mathrm{S}$, Ismael S, editors. Dasar-dasar Metodologi Penelitian Klinis. 2nd ed. Jakarta: CV Sagung Seto; 2002. p.254.

14. Dunn L, Dunn D. Technical Characteristics. In: Dunn L, Dunn D, editors. PPVT 4 Peabody Picture Vocabulary Test. Minneapolis: NCS Pearson, Inc; 2007. p.53-63.

15. Choudhury N, Benasich A. A family aggregation study: the influence of family history and other risk factors on language development. Journal Speech Language Research. 2003;46:261-72.

16. Paul R. Assessment and intervention for emerging language. In: Paul $\mathrm{R}$, editor. Language Disorders from Infancy through Adolescence. 3rd ed. Philadelphia: Saunders Elsevier; 2007. p.266-7.

17. Varma S. Preliminary Item Statistics Using Point-Biserial Correlation and P-Values [Internet]. 2008. Available from: http:// www.eddata.com/resources/publications/ EDS_Point_Biserial.pdf

18. Sidiarto L. Berbagai gangguan berbahasa pada anak. In: Dardjowidojojo S, editor. PELLBA 4 Pertemuan Linguistik Lembaga Bahasa Atma Jaya. Jakarta: Kanisius; 1991. p.135.

\section{APPENDIX}

Table 1. The Validity of Each Item in the $1^{\text {st }}$ Set Compared with the $1^{\text {st }}$ Set Score

\begin{tabular}{ccc}
\hline Item & $\mathbf{r}_{\text {count }}$ & Decision \\
\hline 1 & 0.000 & Not valid \\
2 & 0.000 & Not valid \\
3 & 0.000 & Not valid \\
4 & 0.000 & Not valid \\
5 & 0.000 & Not valid \\
6 & 0.000 & Not valid \\
7 & -0.047 & Not valid \\
8 & 0.241 & Valid \\
9 & 0.000 & Not valid \\
10 & 0.000 & Not valid \\
11 & 0.000 & Not valid \\
12 & 0.355 & Valid \\
\hline & $\mathrm{r}_{\text {Table }}>0.195$ is is assumed valid $(\alpha=0.05 ; \mathrm{n}=100)^{9}$
\end{tabular}


Table 2. The Validity of Each Item in the $2^{\text {nd }}$ Set Compared with the $2^{\text {nd }}$ Set Score

\begin{tabular}{ccc}
\hline Item & $\mathbf{r}_{\text {count }}$ & Decision \\
\hline 13 & 0.000 & Not valid \\
14 & 0.149 & Not valid \\
15 & 0.332 & Valid \\
16 & 0.177 & Not valid \\
17 & 0.186 & Not valid \\
18 & 0.209 & Valid \\
19 & 0.000 & Not valid \\
20 & 0.044 & Not valid \\
21 & 0.148 & Not valid \\
22 & 0.093 & Not valid \\
23 & 0.183 & Not valid \\
24 & 0.092 & Not valid \\
\hline & $\mathrm{r}_{\text {Table }}>0.195$ is is assumed valid $(\alpha=0.05 ; \mathrm{n}=100)^{9}$
\end{tabular}

Table 3. The Validity of Each Item in the $3^{\text {rd }}$ Set Compared with the $3^{\text {rd }}$ Set Score

\begin{tabular}{ccc}
\hline Item & $\mathbf{r}_{\text {count }}$ & Decision \\
\hline 25 & 0.542 & Valid \\
26 & 0.340 & Valid \\
27 & 0.215 & Valid \\
28 & 0.054 & Not valid \\
29 & -0.100 & Not valid \\
30 & 0.358 & Valid \\
31 & 0.134 & Not valid \\
32 & 0.427 & Valid \\
33 & 0.245 & Valid \\
34 & 0.019 & Not valid \\
35 & 0.497 & Valid \\
36 & 0.270 & Valid \\
\hline & $\mathrm{r}_{\text {Table }}>0.195$ is is assumed valid $(\alpha=0.05 ; \mathrm{n}=100)^{9}$
\end{tabular}

Table 4. The Validity of Each Item in the $4^{\text {th }}$ Set Compared with the $4^{\text {th }}$ Set Score

\begin{tabular}{ccc}
\hline Item & $\mathbf{r}_{\text {count }}$ & Decision \\
\hline 37 & 0.020 & Not valid \\
38 & 0.476 & Valid \\
39 & 0.643 & Valid \\
40 & 0.233 & Valid \\
41 & 0.261 & Valid \\
42 & 0.088 & Not valid \\
43 & 0.271 & Valid \\
44 & 0.621 & Valid \\
45 & -0.035 & Valid \\
46 & 0.277 & Valid \\
\hline
\end{tabular}




\begin{tabular}{ccc}
\hline 47 & 0.643 & Valid \\
48 & 0.201 & Valid \\
\hline & $\mathrm{r}_{\text {Table }}>0.195$ is is assumed valid $(\alpha=0.05 ; \mathrm{n}=100)^{9}$
\end{tabular}

Table 5. The Validity of Each Item in the $5^{\text {th }}$ Set Compared with the $5^{\text {th }}$ Set Score

\begin{tabular}{ccc}
\hline Item & $\mathbf{r}_{\text {count }}$ & Decision \\
\hline 49 & 0.455 & Valid \\
50 & 0.419 & Valid \\
51 & 0.304 & Valid \\
52 & 0.336 & Valid \\
53 & 0.346 & Valid \\
54 & 0.296 & Valid \\
55 & 0.246 & Valid \\
56 & 0.419 & Valid \\
57 & 0.510 & Valid \\
58 & 0.244 & Valid \\
59 & 0.231 & Valid \\
60 & 0.253 & Valid \\
\hline & $\mathrm{r}_{\text {Table }}>0.195$ is is assumed valid $(\alpha=0.05 ; \mathrm{n}=100)^{9}$
\end{tabular}

Table 6. The Validity of Each Item in the $6^{\text {th }}$ Set Compared with the $6^{\text {th }}$ Set Score

\begin{tabular}{ccc}
\hline Item & $\mathbf{r}_{\text {count }}$ & Decision \\
\hline 61 & 0.325 & Valid \\
62 & 0.183 & Not valid \\
63 & 0.209 & Valid \\
64 & 0.201 & Valid \\
65 & 0.200 & Valid \\
66 & 0.273 & Valid \\
67 & 0.313 & Valid \\
68 & 0.203 & Valid \\
69 & 0.385 & Valid \\
70 & 0.175 & Not valid \\
71 & 0.374 & Valid \\
72 & 0.375 & Valid \\
\hline & $\mathrm{r}_{\text {Table }}>0.195$ is is assumed valid $(\alpha=0.05 ; \mathrm{n}=100)^{9}$
\end{tabular}

Table 7. The Validity of Each Item in the $7^{\text {th }}$ Set Compared with the $7^{\text {th }}$ Set Score

\begin{tabular}{ccc}
\hline Item & $\mathbf{r}_{\text {count }}$ & Decision \\
\hline 73 & 0.341 & Valid \\
74 & 0.222 & Valid \\
75 & 0.536 & Valid \\
\hline
\end{tabular}




\begin{tabular}{lcc}
\hline 76 & 0.535 & Valid \\
77 & 0.443 & Valid \\
78 & 0.165 & Not valid \\
79 & 0.112 & Not valid \\
80 & 0.172 & Not valid \\
81 & 0,420 & Valid \\
82 & 0.273 & Valid \\
83 & 0.587 & Valid \\
84 & 0.417 & Valid \\
\hline & $\mathrm{r}_{\text {Table }}>0.195$ is is assumed valid $(\alpha=0.05 ; \mathrm{n}=100)^{9}$
\end{tabular}

Table 8. The Validity of Each Item in the $8^{\text {th }}$ Set Compared with the $8^{\text {th }}$ Set Score

\begin{tabular}{ccc}
\hline Item & $\mathbf{r}_{\text {count }}$ & Decision \\
\hline 85 & 0.835 & Valid \\
86 & 0.324 & Valid \\
87 & 0.440 & Valid \\
88 & 0.514 & Valid \\
89 & 0.435 & Valid \\
90 & 0.675 & Valid \\
91 & 0.488 & Valid \\
92 & 0.422 & Valid \\
93 & 0.639 & Valid \\
94 & 0.529 & Valid \\
95 & 0.338 & Valid \\
96 & 0.170 & Not valid \\
\hline \multicolumn{2}{c}{$\mathrm{r}_{\text {Table }}>0.195$ is is assumed valid $(\alpha=0.05 ; \mathrm{n}=100)^{9}$}
\end{tabular}

Table 9. The Validity of Each Item in the $9^{\text {th }}$ Set Compared with the $9^{\text {th }}$ Set Score

\begin{tabular}{ccc}
\hline Item & $\mathbf{r}_{\text {count }}$ & Decision \\
\hline 97 & 0.300 & Valid \\
98 & 0.788 & Valid \\
99 & 0.547 & Valid \\
100 & 0.339 & Valid \\
101 & 0.850 & Valid \\
102 & 0.880 & Valid \\
103 & 0.369 & Valid \\
104 & 0.769 & Valid \\
105 & 0.220 & Valid \\
106 & 0.224 & Valid \\
107 & 0.305 & Valid \\
108 & 0.536 & Valid \\
\hline & $\mathrm{r}_{\text {Table }}>0.195$ is is assumed valid $(\alpha=0.05 ; \mathrm{n}=100)^{9}$
\end{tabular}


Table 10. The Validity of Each Item in the $10^{\text {th }}$ Set Compared with the $10^{\text {th }}$ Set Score

\begin{tabular}{ccc}
\hline Item & $\mathbf{r}_{\text {count }}$ & Decision \\
\hline 109 & 0.794 & Valid \\
110 & 0.551 & Valid \\
111 & 0.271 & Valid \\
112 & 0.559 & Valid \\
113 & 0.411 & Valid \\
114 & 0.624 & Valid \\
115 & 0.356 & Valid \\
116 & 0.520 & Valid \\
117 & 0.759 & Valid \\
118 & 0.276 & Valid \\
119 & 0.225 & Valid \\
120 & 0.667 & Valid \\
\hline & $\mathrm{r}_{\text {Table }}>0.195$ is is assumed valid $(\alpha=0.05 ; \mathrm{n}=100)^{9}$
\end{tabular}

Table 11. The Validity of Each Item in the $11^{\text {th }}$ Set Compared with the $11^{\text {th }}$ Set Score

\begin{tabular}{ccc}
\hline Item & $\mathbf{r}_{\text {count }}$ & Decision \\
\hline 121 & 0.483 & Valid \\
122 & 0.411 & Valid \\
123 & 0.568 & Valid \\
124 & 0.701 & Valid \\
125 & 0.940 & Valid \\
126 & 0.560 & Valid \\
127 & 0.672 & Valid \\
128 & 0.940 & Valid \\
129 & 0.506 & Valid \\
130 & 0.471 & Valid \\
131 & 0.898 & Valid \\
132 & 0.181 & Not valid \\
\hline & $\mathrm{r}_{\text {Table }}>0.195$ is is assumed valid $(\alpha=0.05 ; \mathrm{n}=100)^{9}$
\end{tabular}

Table 12. The Validity of Each Item in the $12^{\text {th }}$ Set Compared with the $12^{\text {th }}$ Set Score

\begin{tabular}{ccc}
\hline Item & $\mathbf{r}_{\text {count }}$ & Decision \\
\hline 133 & 0.618 & Valid \\
134 & 0.634 & Valid \\
135 & 0.454 & Valid \\
136 & 0.375 & Valid \\
137 & 0.838 & Valid \\
138 & 0.863 & Valid \\
139 & 0.370 & Valid \\
140 & 0.356 & Valid \\
\hline
\end{tabular}




\begin{tabular}{ccc}
\hline 141 & 0.718 & Valid \\
142 & 0.536 & Valid \\
143 & 0.411 & Valid \\
144 & 0.832 & Valid \\
\hline \multicolumn{2}{l}{$\mathrm{r}_{\text {Table }}>0.195$ is is assumed valid $(\alpha=0.05 ; \mathrm{n}=100)^{9}$}
\end{tabular}

Table 13. The Validity of Each Item in the $13^{\text {th }}$ Set Compared with the $13^{\text {th }}$ Set Score

\begin{tabular}{ccc}
\hline Item & $\mathbf{r}_{\text {count }}$ & Decision \\
\hline 145 & 0.902 & Valid \\
146 & 0.743 & Valid \\
147 & 0.882 & Valid \\
148 & 0.837 & Valid \\
149 & 0.548 & Valid \\
150 & 0.618 & Valid \\
151 & 0.894 & Valid \\
152 & 0.723 & Valid \\
153 & 0.743 & Valid \\
154 & 0.459 & Valid \\
155 & 0.503 & Valid \\
156 & 0.665 & Valid \\
\hline & $\mathrm{r}_{\text {Table }}>0.195$ is is assumed valid $(\alpha=0.05 ; \mathrm{n}=100)^{9}$
\end{tabular}

Table 14. The Validity of Each Item in the $14^{\text {th }}$ Set Compared with the $14^{\text {th }}$ Set Score

\begin{tabular}{ccc}
\hline Item & $\mathbf{r}_{\text {count }}$ & Decision \\
\hline 157 & 0.234 & Valid \\
158 & 0.453 & Valid \\
159 & 0.587 & Valid \\
160 & 0.630 & Valid \\
161 & 0.230 & Valid \\
162 & 0.595 & Valid \\
163 & 0.512 & Valid \\
164 & 0.339 & Valid \\
165 & 0.382 & Valid \\
166 & 0.486 & Valid \\
167 & 0.795 & Valid \\
168 & 0.855 & Valid \\
\hline \multicolumn{2}{r}{$\mathrm{r}_{\text {Table }}>0.195$ is is assumed valid $(\alpha=0.05 ; \mathrm{n}=100)^{9}$}
\end{tabular}


Table 15. The Validity of Each Item in the $15^{\text {th }}$ Set Compared with the $15^{\text {th }}$ Set Score

\begin{tabular}{ccc}
\hline Item & $\mathbf{r}_{\text {count }}$ & Decision \\
\hline 169 & 0.599 & Valid \\
170 & 0.670 & Valid \\
171 & 0.795 & Valid \\
172 & 0.686 & Valid \\
173 & 0.408 & Valid \\
174 & 0.497 & Valid \\
175 & 0.448 & Valid \\
176 & 0.787 & Valid \\
177 & 0.917 & Valid \\
178 & 0.507 & Valid \\
179 & 0.703 & Valid \\
180 & 0.940 & Valid \\
\hline \multicolumn{2}{r}{$\mathrm{r}_{\text {Table }}>0.195$ is is assumed valid $(\alpha=0.05 ; \mathrm{n}=100)^{9}$}
\end{tabular}

Table 16. The Validity of Each Item in the $16^{\text {th }}$ Set Compared with the $16^{\text {th }}$ Set Score

\begin{tabular}{ccc}
\hline Item & $\mathbf{r}_{\text {count }}$ & Decision \\
\hline 181 & 0.397 & Valid \\
182 & 0.974 & Valid \\
183 & 0.817 & Valid \\
184 & 0.937 & Valid \\
185 & 0.473 & Valid \\
186 & 0.974 & Valid \\
187 & 0.974 & Valid \\
188 & 0.718 & Valid \\
189 & 0.620 & Valid \\
190 & 0.800 & Valid \\
191 & 0.332 & Valid \\
192 & 0.599 & Valid \\
\hline \multicolumn{2}{c}{$\mathrm{r}_{\text {Table }}>0.195$ is is assumed valid $(\alpha=0.05 ; \mathrm{n}=100)^{9}$}
\end{tabular}

Table 17. The Validity of Each Item in the $17^{\text {th }}$ Set Compared with the $17^{\text {th }}$ Set Score

\begin{tabular}{ccc}
\hline Item & $\mathbf{r}_{\text {count }}$ & Decision \\
\hline 193 & 0.353 & Valid \\
194 & 0.894 & Valid \\
195 & 0.481 & Valid \\
196 & 0.737 & Valid \\
197 & 0.831 & Valid \\
198 & 0.755 & Valid \\
199 & 0.813 & Valid \\
200 & 0.902 & Valid \\
\hline
\end{tabular}




\begin{tabular}{ccc}
\hline 201 & 0.578 & Valid \\
202 & 0.678 & Valid \\
203 & 0.227 & Valid \\
204 & 0.971 & Valid \\
\hline & $\mathrm{r}_{\text {Table }}>0.195$ is is assumed valid $(\alpha=0.05 ; \mathrm{n}=100)^{9}$
\end{tabular}

Table 18. The Validity of Each Item in the $18^{\text {th }}$ Set Compared with the $18^{\text {th }}$ Set Score

\begin{tabular}{ccc}
\hline Item & $\mathbf{r}_{\text {count }}$ & Decision \\
\hline 205 & 0.837 & Valid \\
206 & 0.638 & Valid \\
207 & 0.493 & Valid \\
208 & 0.936 & Valid \\
209 & 0.364 & Valid \\
210 & 0.903 & Valid \\
211 & 0.194 & Not valid \\
212 & 0.492 & Valid \\
213 & 0.449 & Valid \\
214 & 0.194 & Not valid \\
215 & 0.529 & Valid \\
216 & 0.929 & Valid \\
\hline & $\mathrm{r}_{\text {Table }}>0.195$ is is assumed valid $(\alpha=0.05 ; \mathrm{n}=100)^{9}$
\end{tabular}

Table 19. The Validity of Each Item in the $19^{\text {th }}$ Set Compared with the $19^{\text {th }}$ Set Score

\begin{tabular}{ccc}
\hline Item & $\mathbf{r}_{\text {count }}$ & Decision \\
\hline 217 & 0.254 & Valid \\
218 & 0.975 & Valid \\
219 & 0.707 & Valid \\
220 & 0.677 & Valid \\
221 & 0.774 & Valid \\
222 & 0.000 & Not valid \\
223 & 0.774 & Valid \\
224 & 0.975 & Valid \\
225 & 0.869 & Valid \\
226 & 0.817 & Valid \\
227 & 0.975 & Valid \\
228 & 0.426 & Valid \\
\hline & $\mathrm{r}_{\text {Table }}>0.195$ is is assumed valid $(\alpha=0.05 ; \mathrm{n}=100)^{9}$
\end{tabular}

